\title{
Bilimkurgu Sinemasında Ekolojik Adalet ve Ekoeleștiri
}

\author{
Aygün Şen \\ Marmara Üniversitesi illetişim Fakültesi \\ aygunsen007@gmail.com
}

\section{Öz}

Ekolojik limitleri görmezden gelerek sürekli büyümeyi teșvik eden kapitalizm, bilim ve teknolojideki gelișmeleri sermayenin hizmetine sunarak gezegenin tüm kaynaklarını sömürmektedir. Ekonomi politikten bağımsız ele alınamayacak ekolojik sorunların ortaya konulması, geniș kitleler tarafından tartıșılması ve çözüm üretilmesi için sosyal bilimler yaklașımına ihtiyaç vardır. Sinema gibi geniș kitlelere ulașan kültürel metinlerin farkındalık yaratma, kamuoyu olușturma gücü göz önüne alındığında, insanmerkezci bir dünya görüșü yerine ekomerkezci bir paradigma inșa edilmesi, ekosistemi meydana getiren tüm canlılar için sosyal ve çevresel adalet mücadelesi verilmesi konusunda eko-sinemanın ve eko-eleștirinin önemli bir rol üstlenmesi gereği anlașılmaktadır.

Son dönem bilimkurgu sinemasında sıklıkla kullanılan ekolojik kıyamet senaryoları biçim değiștirmekte, ekosistemin yıkımında herkesin eșit sorumluluğa sahip olduğu, tüm insanların felaketlerden aynı oranda zarar gördüğü anlatıların yerini sınıfsal bir perspektifle sistemi eleștiren filmler almaktadır. Çalıșmada ekolojik sorunları ele alıp kıyamet sonrası vizyonunu ortaya koyarken sistem eleștirisini ve çevresel adaleti anlatının merkezine yerleștiren bilimkurgu filmler incelenmiștir. Seçilen filmler sosyal ve çevresel adalet, doğa/kültür düalizmi, sömürgecilik, toplumsal meseleler çerçevesinde ekoeleștirel yaklașımla ele alınmıștır.

Anahtar Kelimeler: Ekoeleștiri, ekolojik adalet, sosyal adalet, ekolojik kriz, bilimkurgu sineması.

Makale geliș tarihi: 28.12.2017 • Makale kabul tarihi: 27.02.2018

http://ilefdergisi.org/2018/5/1/

ilef dergisi · (c) $2018 \cdot 5(1) \cdot$ bahar/spring: 31-59

DOI: ilef. 427036 


\title{
Ecological Justice and Ecocriticism in Science Fiction Cinema
}

Aygün Şen

Marmara University Faculty of Communication

aygunsen007@gmail.com

\begin{abstract}
Capitalism, encouraging continuous growth by ignoring ecological limits, exploits all the resources of the planet by bringing the developments in science and technology to the service of the capital. There is a need for a social sciences approach to reveal ecological problems that can not be handled independently from political economy, to be discussed by broad masses and to produce solutions. When eco-cinema and eco-criticism are considered as important for the struggle for social and environmental justice for all living creatures bringing ecosystem to the fruition, building an ecocentric paradigm instead of a anthropocentric world view, considering the power of creating awareness and publicity of cultural texts reaching wider masses such as cinema role to be undertaken.

The ecological apocalyptic scenarios often used in recent science fiction cinema are films that criticize the system with a class perspective in the form of changing forms, having everyone on an equal footing in the destruction of the ecosystem, and all people suffering in the same way as disasters. While studying ecological problems and putting forth the post-apocalyptic vision, science fiction films that put system criticism and environmental justice at the center of the narrative were examined. Selected films have been dealt with in the context of social and environmental justice, nature / culture dualism, colonialism, social issues in an ecocentric manner.
\end{abstract}

Keywords: Ecocriticism, Ecological Justice, Social Justice, Ecological Crisis, Science Fiction Film. 
İnsan toplumunun doğadan kopuşu yüzlerce yıl önce toprağın mülk edinilmesi ile başlamıs, dinsel inanışlar, felsefe, bilim ve siyasetteki dönüşümler doğanın hammadde kaynağı olarak görülmesi sürecini hızlandırarak medeniyetin ve ilerlemenin doğaya hükmetmek olarak algılanmasını desteklemiştir. Endüstriyel Devrim ile bu zihinsel sürecin teknik yönü tamamlanmış, ekosistemin bir parçası olduğunu unutan insan türünün doğada neden olduğu yıkım tüm gezegenin sağlığını tehdit eder hale gelmiştir. Dinsel inanışlar, insan merkezci bilim, sanayi devrimi ve kapitalizm ile doğallaştırılan kültür / doğa karşıtllğı ve doğanın sömürüsü, küreselleşmenin de etkisiyle ekosisteme onarilamaz zararlar vermeye devam etmektedir.

Doğanın belirli yasalara göre işlediğinin kabulü dışında 17. yüzyıl bilimsel devrimi ve ona bağlı gelişen modern bilimin "doğanın fethi ve üzerinde hâkimiyet kurulması" fikrine dayandığını belirten John Bellamy Foster, 20. yüzyıl sonundaki ekolojik hareketin yükselişine kadar kapitalizmin -bazen de sosyalizmin- doğayı fethetmenin "ilerlemeyi" anlatan bir mecaz olduğunu vurgulamıştır. ${ }^{1}$ 20. yüzyılın ikinci yarısından itibaren dünyanın karşı karşıya kaldığı ekolojik yıkım, çevre krizinin sosyo-politik yönlerinin araştırılmasına duyulan ihtiyacı ortaya koymuştur. İnsan toplumunun tüm doğal varlıklarla birlikte kendi türünün devamlılığını da tehdit eden bir "medeniyet" kurması 
ekolojik sorunların sadece teknoloji ve fen bilimlerinin yardımı ile çözülemeyeceğini açıkça göstermiştir. Modern düşünceyi, insan kültürünü ve medeniyetini oluşturan tüm bileşenler ekolojik bir perspektifle tartışmaya açılmış, ekolojinin salt doğa biliminin konusu olmadığı, teknoloji ile çözülemeyecek kadar derin ve yapısal sorunlarla yüz yüze gelindiği anlaşılmıştır.

Foster "Ekoloji ve Kapitalizmden Sosyalizme Geçiş" makalesinde yaşadığımız dönemde karşı karşıya bulunduğumuz ekolojik krizin sermaye birikiminin "dünyayı yabancılaştırıcı” mantığına yerleşik olduğunu ve bir sistem olarak kapitalizmin köklerine dayandığını vurgulamıştır. ${ }^{2}$ Günümüzde insan türü küresel iklim değişikliğinden endüstriyel çöp yığınlarına kadar değişen bir ölçekte çevresel yıkım yoluyla kendi yaşamını ve ekosistemin sağlığını tehdit etmeye devam etmektedir. Zenginliğin mevcut dağılımı, dünyanın pek çok bölgesinde besin ve temiz suya ulaşamayan kitleler yaratmakta, insan nüfusu artmaya devam ederken gereksiz şekilde yıkıcı türde endüstrileşmiş tarıma yol açmaktadır. Biyo-çeşitlilik hızla düşerken ve türler ortadan kaybolurken, insan toplumları ekonomik ve endüstriyel anlamda sürekli büyümeye ve sosyal-ekonomik-çevresel adaletsizliğe dayalı olan, ekosistemin taşıma kapasitesini aşan bir sistemi devam ettirmeye çalışmaktadır.

Edebiyat alanında doğa üzerine yazılmış eserlerin incelenmesi ile başlayarak günümüzde tüm kültürel ürünleri içine alacak şekilde genişleyen ekoeleştiri çalışmaları, kültürel metinlerde insana verilen ayrıcalıklı rolü sorgulayarak doğanın tüm varlıklarına özne konumunu geri vermeyi amaçlamaktadır. Ekolojik bozulmaya neden olan yerleşik değer yargılarını, ön kabulleri tartışmaya açarak okuyucularında bilinç değişikliği ve devamında davranış değişikliği gerçekleştirmeyi amaçlar. Kültürel metinlerdeki doğa temsillerini ele alarak bu temsillerin sorunlu ve eksik yönlerini deşifre eder, doğanın kendi adına konuşmasına olanak tanır ve insanın doğa ile olan karşılıklı bağına vurgu yapar. İnsanın ekosisteme zarar veren toplumsal, politik, ekonomik sistemlere karşı çıkmasının ilk aşaması, öncelikle tüm türlerin kendi içsel değeri olduğunun, insana sağladıkları faydadan bağımsız bir değer taşıdıklarının farkına varmasıdır.

Ekolojik yıkımda insan eylemlerinin rolü günümüzde açık biçimde tartışılmakla birlikte her bireyin eşit suç ve sorumluluğa sahip olduğunu iddia etmek, küresel şirketlerin ve hükümetlerin süreçteki rolünü gözden kaçırmak anlamına gelmektedir. Bir yanda doğaya her gün tonlarca atık bırakan dev şirketler ve doğayı şirketlerin sömürüsüne açan hükümetler, diğer yanda Küresel Kuzey'in sınırsız tüketimi için sağlıksız koşullarda çalıştırılan Küresel 
Güney'in yoksul halkları, Kuzey ülkelerinde yaşayan alt sınıflar, azınlıklar ve yerli halklar; bu iki taraf bugün karşı karşıya kaldığımız krizde elbette eşit sorumluluğa sahip değildir. Ekoeleştirel çalışmalar içinde çevre etiği, ekolojik adalet, yerli halkların mücadeleleri gibi eşitlik ve adalet temelli yaklaşımlar giderek daha fazla yer bulmaktadır. Bilimkurgu sinemasında sıklıkla işlenen kıyamet öykülerinde ekolojik felaketlerin sebepleri ve sonuçları ele alınırken, son dönemde artan sayıda filmde mevcut ekonomik/politik sistem eleştirilmekte ve ekolojik adalet meselesi öykünün odağında işlenmektedir.

\section{Ekolojik Kriz ya da Homo-economicus'un Krizi}

1999'da Guardian Weekly'de yayımlanan Paul Brown'ın makalesi ekolojik krizin boyutlarını ortaya koymak bakımından önemli veriler sunmaktadır. 1998 yılında kuraklık, sel, ormanların yok edilmesi ve toprakların verimsizleşmesi gibi nedenler yüzünden göç etmek zorunda kalan insan sayısı 25 milyonu bulmuş, ilk kez savaş nedeniyle göç etmek zorunda kalan insan sayısını geride bırakmıştır. Her yıl yapılan World Disasters (Dünyadaki Felaketler) adlı araştırmanın 1999 yılı raporuna göre, 1998 yılında meydana gelen “doğal felaketler" rekor düzeye ulaşmış, bu felaketler nedeniyle yerini yurdunu terk etmek zorunda kalanlar dünya genelindeki mültecilerin $\% 58$ 'ini oluşturmuştur. Araştırmayı yapan uluslararası federasyonun başkanı Astrid Heiberg'in de vurguladığı gibi, küresel ısınma ve ormanların yok edilmesinden kaynaklanan ekolojik sorunlar ile yoksulluk ve gecekondu sayısındaki artışla kendini gösteren toplumsal sorunların bir araya gelmesiyle felaket yepyeni boyutlara ulaşmaktadır. Heiberg, insan kaynaklı iklim değişikliği ile hızla değişen toplumsal ve ekonomik koşulların bir arada çok daha büyük boyutlu felaketlere yol açacak zincirleme bir reaksiyon başlatacağı konusunda uyarıda bulunmuştur. ${ }^{3}$

Birleşmiş Milletler Gıda ve Tarım Örgütü'nün (FAO) 2017 Küresel Gıda Krizi Raporu'na göre küresel olarak, 2016 yılında 108 milyon kişi kriz düzeyinde gıda güvensizliği veya daha kötüsü ile karşı karşıya kalmıştır. Bu sayı, 80 milyon olarak tespit edilen 2015 yılına göre \%35'lik bir artış olduğunu ortaya koymaktadır. Küresel iklim değişikliğine bağlı kuraklık ve El Nino gibi meteorolojik felaketlerin yanı sıra Yemen, Suriye, Irak gibi ülkelerde devam eden şiddetli çatışma koşulları da gıda güvenliğini tehdit etmektedir. Uzmanlar küresel iklim değişikliği ve bölgesel çatışmaların kalıcı doğasının, ayrıca bunlara bağlı olarak zincirleme şeklinde artan etkilerin risk altındaki toplulukların mevcut durumla başa çıkma ve gelecek şoklara direnme kapasitesini zayıflattı̆̆ına değinmiştir. ${ }^{4}$ 
2015 yılı Birleşmiş Milletler Dünya Su Gelişim Raporu (WWDR) tek başına ekonomik büyümenin geniş çaplı bir toplumsal ilerlemenin göstereni olmadığını, pek çok ülkede temel insan hakkı olan temiz su ve hıfzıssıhhaya erişim olanakları bakımından zenginler ve yoksullar arasında büyüyen bir uçurum olduğunu belirtmiştir. Küresel iklim değişikliği ve deniz seviyesindeki yükselmenin tatlı su kaynaklarının azalmasına sebep olduğu günümüzde temiz suya erişimin sosyal adalet çerçevesinde düzenlenmemesi özellikle yoksullar, kadınlar ve çocuklar üzerinde orantısız etkilere neden olmaktadır. ${ }^{5}$

İklim değişikliği, türlerin çeşitliliğinin azalması, zehirli atıklar, kuraklık, besin kıtlığı gibi sorunlar küresel ekolojik meseleler olmakla birlikte bu sorunlar öncelikle yoksul halkları etkilemektedir. Zehirli atık bölgelerinde yaşamak zorunda kalanlar, kuraklık yüzünden tarım yapamayanlar, gıda sıkıntısı çekenler yoksul Güney ülkeleri halkları ve zengin Kuzey ülkelerinin yoksul ve azınlık durumundaki halklarıdır. Küresel çapta faaliyet yürüten şirketler Amazon'u petrol atıkları ile zehirlemekte, endüstriyel tarımcılığa arazi sağlamak için ormanları yok etmekte, çalışanların sağlığını tehlikeye atan endüstriyel faaliyetlerini yoksul ülkelerde sürdürmekte, yerli halk tarafından kutsal sayılan ve ekosistemin bir parçası olan nehirlere sayısız baraj inşa ederek bölgenin yaşam kaynağı olan suyu tekeline almayı amaçlamaktadır. ${ }^{6}$

\section{Ekolojik Adalet: Ekolojik Mücadele ve Sınıf Mücadelesi}

Joel Kovel ekolojik krizi, doğanın insani üretimi tamponlama kapasitesini sistemli olarak tahrip eden ve nihayet aşan, ekosistemlerde hangi sonuçlara yol açacağı önceden kestirilemeyen, ancak birbiriyle etkileşim halinde olan ve sürekli genişleyen bir dizi çöküş olarak açıklamıştır. Bu aşamada hayat döngülerin birbirine bağlı ve uyumlu işleyişleri aksamakta, insani ekosistemler kadar diğer ekosistemler de parçalanmaktadır. ${ }^{7}$ Murray Bookchin'e göre, çağımızda karşı karşıya kaldığımız ekolojik krizin temel nedeni, günümüz toplumunun organik evrimi geçmişteki tüm toplumlardan daha fazla bozuyor olmasıdır. Günümüzde toplumun geldiği yıkıcı, yok edici ve sömürücü noktayı anlamak için sadece nüfus ve teknoloji üzerine yoğunlaşmak meselenin asıl kaynağını gözden kaçırmamıza neden olur. Uygarlıkla beraber başlayan hiyerarşi ve tahakkümün kaynağını oluşturan kurumsal ve ahlaki yapılar ortadan kaldırılmadan yapılacak reformlar ya da teknolojiyi tamamen reddetmek, kapitalist mülkiyet ve üretim ilişkilerinden kaynaklanan krizi çözmekte başarısız olacaktır. ${ }^{8}$ 
Tarihte hiçbir toplumun sermaye sahiplerini daha fazla biriktirme, sahte ihtiyaçlar yaratma, daha fazla üretme ve daha fazla satma konusunda destekleyen bir kâr hırsı tarafından yönlendirilmediğini söyleyen Daniel Tanuro, 'ekolojik kriz' olarak adlandırılan olgunun insanlığın çevresiyle olan ilişkisinin tarihsel krizi olduğunu vurgulamıştır. Bir yanda zenginlik ve aşırı tüketim, diğer yanda yoksulluk ve yetersiz tüketimi arttıran bu sistemde, tüm insanları eşit derecede sorumlu tutan 'antropik' (insan kaynaklı) değişim yerine kapitalist iklim değişikliğinden, toplumsal bir krizden söz etmek gerekmektedir. $^{9}$

Joseph Needham'a göre kapitalizmde doğanın fethinden insanın fethine geçilmiş, doğa üzerinde hâkimiyet kurmak için kullanılan teknolojik aygıtlar toplumsal tahakküm mekanizmalarını da dönüştürmüştür. Tüm gezegeni etkisi altına alan tahakküm ve yıkımın sonucu olarak iktisadi anlamda çevre ve merkez ülkeleri arasındaki eşitsizlik ile birlikte kapitalist devletler içindeki sınıflar arasındaki eşitsizlik de artmakta, ekolojik anlamda küresel ekosistem küresel iklim değişikliği tarafından dönüştürülmektedir. ${ }^{10}$

1992 Haziran'ında Rio de Janeiro'da tüm dünya ülkelerinin katıldığ1 Yeryüzü Zirvesi olarak da adlandırılan Birleşmiş Milletler Çevre ve Kalkınma Konferansı gerçekleştirilmiştir. Zirvenin hazırlık çalışmalarının sürdüğü yıllar boyunca ortak bir metin oluşturulabilmesinin önündeki en büyük engel zengin ve yoksul ülkelerin çatışan çıkarları olmuştur. Yeryüzü kaynaklarını en çok kullanan, yeryüzünü en çok tahrip eden zengin ülkeler, bir yandan mevcut üretim ve tüketim alışkanlıklarında anlamlı bir değişimin sözünü vermekten kaçınmakta, diğer yandan yoksul ülkelerdeki endüstriyel faaliyetleri ve nüfus artışını çevre sorunlarını derinleştirecek bir insani etken olarak sunmaktadir. ${ }^{11}$

Küresel nüfus artışına dair kaygıların yeni olmadığını belirten Ursula Heise, Thomas Malthus'un 1789' da yazdı̆̆ 1 An Essay on the Principle of Population (Nüfusun İlkeleri Üzerine Bir Deneme)'den beri insan nüfusundaki hızlı büyümenin geleceğe dair derin endişelere ve vahim öngörülere neden olduğunu hatırlatmıştır. 1960'lar ve 70'lerde Paul Ehrlich'in The Population Bomb (Nüfus Bombası/1968), Roma Kulübü raporu The Limits to Growth (Büyümenin Sinırlar1/1972), ve Lester Brown'in The Twenty-Ninth Day (Yirmi Dokuzuncu Gün/1978) gibi nüfus artışı kontrol altına alınmazsa çevreyi ve küresel toplumu bekleyen korkunç bir gelecek öngören yayınlarla nüfus artışına dair kaygilar doruğa ulaşmıştır. ${ }^{12}$ 
Malthus'un yaklaşımı, "sefaletin bir yere düşmesi" gerektiğini ve kaçınılmaz olarak bu yerin alt sınıflar olduğunu öne sürer. Alt sınıfların sefaleti, "insan düzenlemesinden tamamen bağımsız" işlediğini iddia ettiği doğa kanununun sonucudur. Azlık tanımının kökeninin ayrışmaz biçimde toplumsal ve kültürel olmasına rağmen genellikle doğaya içkin bir şey olarak kabul edildiğini belirten David Harvey, deneyimlediğimiz azlıkların çoğunun doğadan kaynaklanmadığını, insan faaliyetleri tarafından yaratılıp toplumsal idare yoluyla yönetildiğini ortaya koymuştur. "Aslında azlık, kapitalist üretim tarzının ayakta kalmasında zorunludur ve dikkatle idare edilmesi gerekir, yoksa fiyat mekanizmasının kendi kendini yöneten tarafı parçalara ayrılır."13

Harvey'nin vurguladığı gibi, nüfus fazlalığı ve kaynak azlığı argümanı kabul edilip kapitalist üretim biçiminin devam etmesine izin verildiği sürece, yurt içinde sınıfa ve etnik baskılamaya yönelen politikalar, sınır ötesinde de emperyalist ve neo-emperyalist politikalar kaçınılmaz olacaktır. Mevcut bir toplumsal düzen, bir nevi elit grup tehdit altındaysa, egemen konumunu korumak için mücadele ediyorsa, nüfus fazlalığı ve kaynak azlığı argümanları insanları statükoyu ve otoriter ölçütleri benimsemeleri yönünde ikna etmeye yarayan ideolojik aygitlar olarak işlev görür. ${ }^{14}$ "İnsanlar bir kez kendi coğrafi, toplumsal ve zihinsel habitatlarında kendilerini kısıtlanmış hissetmeye başladı mı" diye yazar Levi-Strauss, "türün bir kesiminin insan olarak görülme hakkını inkâr etme gibi basit bir çözümün cazibesine kapılma tehlikesine düşerler" ${ }^{15}$

Bilimkurgu sinemasında son dönem kıyamet ve kıtlık senaryoları da benzer şekilde insan türünün felaket karşısında ya da kaynakların sadece bir grup insana yeteceğine inandıkları zaman halkın belli bir kısmını "insan olmayan öteki" olarak görme eğilimini ele alan filmlerdir. Çalışmada ele alınan Avatar (James Cameron, 2009), Snowpiercer (Kar Küreyici, Joon-ho Bong, 2013), Elysium (Yeni Cennet, Neill Bloomkamp, 2013), Hunger Games (Açlık Oyunları, Gary Ross,2012/Francis Lawrence, 2013, 2014, 2015) gibi distopyan bilimkurgu filmler, ekolojik mahşer sonrası dünyasında kıt kaynakların sosyal ve çevresel adalet ekseninde nasıl bir baskı ve denetim mekanizması haline geleceğine dair endişelerin dile getirildiği popüler anlatılardır.

Rob Nixon Slow Violence and the Environmentalism of the Poor (Yavaş Şiddet ve Yoksulların Çevreciliği) adlı kitabında ekoeleştirinin çalışma alanlarından sosyal ve çevresel adalet kavramını Üçüncü Dünya'nın ekolojik mücadeleleri bakımından ele almıştır. Nixon "yavaş şiddet" $i$ aşama aşama ve gözden uzakta gerçekleşen, zamana ve mekâna yayılmış ertelenmiş yıkımın şiddeti, 
normalde bir şiddet gibi görülmeyen aşındırıcı şiddet olarak açıklamıştır. Şiddet aniden gerçekleşen, mekânda birden ortaya çıkan ve derhal algılanan bir olay veya eylem olarak algılanır. Ancak yazar, şiddetin başka bir türü ile meşgul olmamız gerektiğini vurgular. Yavaş şiddet, ani ve seyirlik (spectacular) olmayan, zamanda ve mekânda birikerek etkisini artıran, kademeli şekilde ilerleyen ve büyüyen bir şiddettir. İklim değişikliği, ormansızlaşma, okyanusların kirlenmesi, toksik atıklar gibi yavaşça gerçekleşen çevresel felaketlerin algılanmasındaki ve temsil edilmesindeki güçlükler, bu tür şiddetle mücadele etmeyi daha da zorlaştırmaktadır. Nixon, medyanın etkileyici olana ve gösteriye tapındığı, kamu politikalarının derhal algılanan ihtiyaçlara göre biçimlendirildiği bir çağda yavaş şiddetin nasıl temsil edilebileceği sorusu üzerine eğilmiştir. Düşen bedenler, yanan kuleler, tsunami dalgaları gibi dikkat çekici olmayan, on yıllara yayılan yavaş şiddetin algılanmasını nasıl sağlayabiliriz? Yavaş gerçekleşen, anonim olan felaketleri kamunun dikkatini çekmeye ve politik müdahaleyi sağlamaya yetecek görüntülere ve anlatılara nasıl dönüştürebiliriz? ${ }^{16}$

Nixon'un özellikle vurguladığı gibi, yavaş şiddetin temel kurbanları kaynak sıkıntısı çeken yoksullardır. Zengin Kuzey ülkelerinde gelişen çevreciliğin, Andrew Ross'un deyimiyle "gezegensel idare" (planetary management) için başka bir kılıf olduğu görüşü, küresel kaynak savaşlarının cephe hattında ikamet edenler arasında tam olarak giderilmemiştir. Nixon, ekolojik mücadelenin ve dolayısıyla gezegenin sonucunu sınıf temelli bir mücadelenin belirleyeceğini belirtmiştir. "İnanıyorum ki, çevreciliğin kaderi -ve daha kesin olarak biyosferin karakteri- Ramachandra Guha ve Joan Martinez-Alier'in "tok karınlılar" ve "boş mideliler" çevreciliği olarak adlandırdığı hareketler arasındaki gerilime rastlayan dönemde dikkate değer bir şekilde biçimlendirilecek" ${ }^{17}$

Joni Adamson American Indian Literature, Environmental Justice and Ecocriticism (Amerikan Yerli Edebiyatı, Çevresel Adalet ve Ekoeleştiri) adlı kitabında sınır bölgesi halkları ve azınlıkların maruz kaldı ̆̆ı çevresel adaletsizliği ortaya koyar. 1987 tarihli bir rapordan veriler aktaran Adamson, “Afro-Amerikalı ve Hispaniklerin yüzde altmışının, Amerika Yerlileri ve Asya/Pasifik Adalıların yüzde ellisinden fazlasının bir veya daha fazla sayıda denetimsiz zehirli atık bölgesine yakın yaşadığını" belirtir. 2001 yılında yayımlanan kitabıyla ekoeleştirinin pastoral ve yaban hayatla ilgilenmenin ötesinde toplumsal ekolojik bir bakış açısı kazanıp çevresel adalet kavramını ele almasına öncü olan yazar, Amerikan Yerlilerinin çevreyi kirleten endüstrilerinin hem 
çalışanları hem de kurbanları olduğunu vurgular. Adamson, ekoeleştirmenleri doğa kavramına ve doğa yazınına geleneksel bakışı sorgulamaya, birbirlerini etkileyen toplumsal ve çevresel sorunların merkezi olan, üzerinde her geçen gün sayıları artan yoksul ve ötekileştirilmiş insanın yaşadığı topraklar üzerine düşünmeye davet eder. ${ }^{18}$

Aldo Leopold'un görme ve etik üzerine yaklaşımını hatırlatan Nixon, doğayı, "öteki”leri nasıl görebileceğimiz ve anlayabileceğimiz sorusuna eğilmiştir. Leopold'ün "ancak görebildiğimiz şeylere karşı etik olabileceğimizi” vurgulayan sözlerinden yola çıkan yazar, duyusal algı alanımızın ötesinde uzanan insan ve biyotik topluluklara karşı nasıl etik hareket edebileceğimizi sormuştur. Bir yandan yavaş şiddetin görünür olmasını sağlamaya çalışırken aynı zamanda da görünür olana ayrıcalık tanınması ile nasıl mücadele edebiliriz? Nixon, yavaş şiddetin ekosisteme ve ekosistemin bir parçası olan insana zararlarını ortaya koyarken ekolojik ve sosyal adaleti odak noktasına almıştır. Zengin Kuzey ülkelerinin, tek tip üretime mecbur ederek biyotik çeşitliliğine zarar verdiği, ağır sanayilerini taşıdığı, endüstriyel atıklarını ihraç ettiği, sağlıksız koşullarda yavaş yavaş zehirlediği Üçüncü Dünya Ülkeleri insanlarını "kullan at insanlar", söz konusu coğrafyaları ise "kullan at çevreler" olarak gördüğünü belirtmiştir. Yavaş şiddete sadece kimlerin maruz bırakıldığı değil, kimlerin "tanık" sayıldığı da önem taşımaktadır. Şiddet kimin tanıklı̆̆ı ile "şiddet" sayılır?"19

Üçüncü Dünya ülkelerindeki ekolojik katliamlar ve yavaş şiddet, ancak gelişmiş ülkelerin gündemine taşınabilecek gösteriler haline getirildiğinde dünya kamuoyunda ses getirmekte ve çözüm için baskı grupları oluşmaktadır. Bu nedenle ekolojik mücadeleleri yürütmek, sosyal ve ekolojik adaletsizliğe karşı kamuoyu baskısı oluşturarak karar alıcıları harekete geçirmek için popüler kültür ürünleri ile ilişkilendirilen, farklı coğrafyalarda ekolojik mücadeleler veren insanları birleştiren kampanyalar büyük önem taşımaktadır. Sömürülen doğanın, adaletsizliğe uğrayan ve yok sayılan sınıfların, yoksul halkların sesinin duyulması, mücadelelerinin görünür olabilmesi için ekomerkezci kültürel ürünlere ve bu ürünlerin incelendiği ekoeleştirel metinlere ihtiyaç vardır. Ekoeleştirinin hayatî önemi buradan kaynaklanmaktadır: Tutumlarımızı algılarımız biçimlendirir ve somut eyleme giden yolda kültürel inşalar olan algılarımız dönüşüme uğratılmadan ekolojik yıkımın önüne geçmek için gerekli somut adımların atılması mümkün değildir.

21. yüzyılda biyosferik gerçekliklerle, ekosistemin işleyişi ile uyum içinde kolektif ve sürdürülebilir üretim ve tüketim biçimlerini benimsemeden 
insanlığın gelişmeye devam etmesi mümkün değildir. Gezegensel limitleri kabul etmeyen, çözümü sadece teknolojide arayan ve gelişme, kalkınma gibi kavramların kapitalizmin sürekli büyümeye dayanan yıkıcı çerçevesinde tanımlayan hiçbir hareket başarılı olamaz. Somut her ekoloji savunmasının sermaye birikimi mantığını ortadan kaldırmaya dayanması gerektiğini vurgulayan Foster, dünyanın ihtiyaçlarına uygun bir uzun ekolojik devrimin doğanın ve insan emeğinin kapitalizmdeki yabancılaşmasına karşı çıkarak gerçekleştirilebileceğini belirtir. ${ }^{20}$

\section{Ekoloji Mücadelesinde Sosyal Bilimler Yaklașımı: Ekoeleștiri}

Ekoeleştirel çalışmaların ilk örneklerine konu olan doğa yazını, çağdaş biçimiyle ilk kez 19. yüzyılda Henry David Thoreau'nun eserlerinde ortaya çıkmış, 20. yüzyılda Aldo Leopold'un, John Muir'in ABD'nin yabanıl alanlarının korunması için verdikleri mücadeleler ve yazdıkları eserler ile sürmüştür. Serpil Oppermann, ekoeleştirinin ilk dönem çalışmalarının edebiyat eserlerinde çevreci fikirlere ve doğa betimlemelerine odaklandığını belirtmiştir. İlk dönem ekoeleştirmenler insanı doğaya yaklaştırmak ve doğayı "öteki” olmaktan çıkararak onun ontolojik gerçekliğini anlatmak için edebiyattan faydalanmışlardır. ${ }^{21}$

Çevre koruma hareketlerinin $\mathrm{ABD}^{\prime}$ de toplumsal bir hareket olarak ortaya çıkışı ve kabul görmesi 1960'larda başlamıştır. Science and Survival (Bilim ve Sağkalım, 1966), The Closing Circle (Kapanan Çember, 1971), Making Peace with the Planet (Gezegenle Barışmak, 1990) gibi ünlü kitapların yazarı biyolog ve çevre aktivisti Barry Commoner 50'lerin sonlarından itibaren nükleer denemeler, kimyasal atıklar ve enerji politikaları hakkında geniş kitleleri bilinçlendirecek kitaplar yazmıştır. Yeni doğan bebeklerde nükleer denemelerden kalan radyoaktif izleri ortaya koyduğu yayınları ve aktivizmi sayesinde 1963 yılında yer üstü nükleer denemeler yasaklanmıştır. ${ }^{22}$ Biyolog Rachel Carson, 1962'de yayımlanan Silent Spring (Sessiz Bahar) adlı kitabında tarımda kullanılan ilaçların, DDT gibi zehirli kimyasalların doğa üzerinde bıraktığı korkunç etkilere değinmiş, anne sütünde ve henüz doğmamış bebeklerde bu kimyasalların izine rastlandığını ortaya koymuştur. Büyük yankı yaratan ve ABD'de çevreci hareketin başlamasına öncülük eden kitap 1964'te Wilderness Act (Doğa Kanunu) çıkartılmasında ve 1971 yılında DDT'nin kullanımının tamamen yasaklanmasında büyük rol oynamıştır. Oppermann'ın da vurguladığı gibi, yabanıl yaşamın ekolojik, toplumsal, politik ve estetik boyutunu ele alan doğa yazını, çevreciliğin toplumsal hareket haline gelmesinde, ekolojik bilincin gelişmesinde önemli rol oynamıştır. ${ }^{23}$ 
Doğa yazınının ortaya çıkması gibi etkinliğini arttırması da çevre ile olan yakın ilişkinin sonucudur. 1960'larda tarım ilaçlarının etkisi, yabanıl doğal alanların ortadan kaldırılması kaygıları ile görünürlük kazanan çevre hareketi ile doğa yazını birbirini beslemiştir. 1970'lerde ekoeleştiri terimi ilk kez kullanılmış, ancak çalışmacılar birbirinden farklı uzmanlık alanlarında çalışmaya devam ettiklerinden bir çatı altında toplanamayan ekoeleştirel literatür akademik ve toplumsal olarak yeterince etkili olamamıştır. 90'larda çevresel yıkımın göz ardı edilemeyecek boyutlara ulaşması ve gündemde yer bulması ile ekoeleştiri alanında yapılan çalışmaların sayısı artmış, yöntemi ve kapsamı hakkındaki tartışmalar hız kazanmıştır. Cheryll Glotfelty ve Harold Fromm'un 1996 yılında derledikleri The Ecocriticism Reader adlı kitap, 70'lerden beri yazılmış ekoeleştirel metinleri bir araya toplayarak alanın gelişimine büyük katkı yapmıştır.

Joseph W. Meeker The Comedy of Survival: Studies in Literary Ecology (Hayatta Kalmanın Komedisi: Edebi Ekoloji Çalışmaları, 1974) adlı eserinde "literary ecology" (edebî ekoloji) terimini edebi çalışmalarda görülen biyolojik temaların ve bağlantıların araştırılmasına göndermede bulunmak için kullanmıştır. Meeker'a göre, "Bu aynı zamanda, edebiyatın insan türünün ekolojisinde hangi rolü oynadığını keşfetmek için bir girişimdir". Ecocriticism (ekoeleştiri) terimi ise ilk kez 1978'de William Rueckert tarafından Literature and Ecology: An Experiment in Ecocriticism (Edebiyat ve Ekoloji: Ekoeleştiride Bir Deney) adlı makalesinde kullanılmıştır. Rueckert ekoeleştiri ile "ekolojinin ve ekolojik kavramların edebiyat çalışmalarına uygulanışı"nı kastetmiştir. Glotfelty, Rueckert'in tanımının özel olarak ekoloji bilimi ile ilgilendiğini, bu nedenle edebiyat ve fiziksel dünya arasındaki olası tüm ilişkileri kapsayan yaklaşımdan daha kısıtlayıcı olduğunu belirtmiştir. ${ }^{24}$

Paula Willoquet Maricondi'nin anlatımıyla ekoeleştiri, toplumsal cinsiyet, sınıf, etnisite gibi toplumsal inşalar ve doğa arasındaki karşılıklı etkileşimi araştırır. Kültürel metinlerin doğal dünya ile ilişkilerimizi nasıl etkilediğini, kültürün içinde zamanla değişen doğa imgesinin değişimini, çevresel krizin edebiyattaki temsillerini ele alır. "Kısaca, ekoeleştiri dünyanın toplumsal alandan (social sphere) ve ekosferden (ecosphere) oluştuğunu, bu ikisinin karşılıklı ilişki içinde olduğunu ve birincisinin, ikincisinin bağlamı dışında değerlendirilemeyeceğini kabul eder." ${ }^{25}$ Cheryll Glotfelty de ekoeleştiriyi edebiyat ve fiziksel çevre arasındaki ilişki üzerine yapılan çalışmalar olarak tanımlamıştır. Feminist eleştirinin dil ve literatürü toplumsal cinsiyet temelli bir perspektiften incelemesi, Marxist eleştirinin metin okumalarına ekono- 
mik sınıf ve üretim biçimleri üzerine farkındalık geliştirmesi gibi ekoeleştiri de edebi çalışmalara dünya-merkezli bir yaklaşım benimser. ${ }^{26}$ Glotfelty'nin ekoeleştiri tanımına atıfta bulunan Garrard, feminizm ve Marksizmle kıyaslanmasından da anlaşılabileceği gibi, ekoeleştirinin politik bir analiz biçimi olduğunun altını çizmiştir. Kültürel ürünleri incelerken belirgin bir çevreci ahlak ve siyasi gündeme bağlayan ekoeleştiri, felsefedeki ve siyaset kuramındaki ekoloji merkezli gelişmelerle yakından ilişkilidir. Bir bilim dalı olmasının yanında toplumsal-politik bir hareket olan ekolojinin zamanla değişen, dönüşen bir tanım olduğunu hatırlatan Garrard, "esas olan ekoeleştirinin ahlaki ve siyasi yönelimi vurgusu ve çalışma alanının geniş tanımıdır" der. $^{27}$

“Doğa onun hakkında söylediklerimizden bağımsız olarak varlığını sürdürür sürdürmesine, ama bizim için ancak onun hakkında bir şeyler söylediğimiz sürece vardır" diyen ekososyalist Joel Kovel, dilin gerçeği "yarım yamalak yansıtan bir ayna" olmasının yanında toplumsal ve tarihsel bir inşa olduğuna dikkat çekmiştir. Düşünüre göre insanın doğa üzerinde bıraktığı iz iki katmanlıdır; insan türü doğayı hem somut olarak etkileyerek, onu yeniden biçimlendirerek ve düzenleyerek kendi izini yerkürenin her noktasına bırakır, hem de doğal dünyaya dair tüm önermeler toplumsal sözcelerdir. Doğadan bahsetme yolları kültürün dolayımından geçmiş dil ile ifade edilir ve bunlar toplumsal pratiklerdir. ${ }^{28}$ Greg Garrard da ekoeleştirmenlerin doğanın bir yönüyle kültürel bir inşa olduğunu fark edip bunlar üzerinde çalışırken, diğer yandan doğanın nesne ve dolaylı biçimde söylemin kökeni olarak gerçekten var olduğunu gözden kaçırmamaları gerektiğini hatırlatmıştır. ${ }^{29}$

Tanımlamak, anlamak, etik bir ilişki oluşturmak için doğayı sözcüklerle, görüntülerle, seslerle ifade etmemiz gerekir. Bu nedenle ekolojik yıkımın önüne geçmek için öncelikle kültürün öğeleri ele alınmalı, insanmerkezci bakışı normalleştiren kavramlar sorgulanmalı, yeni kavramlar ve yeni yaklaşımlar üzerinde uzlaşılmalıdır. Yazılı eserlerde doğa temsillerini incelemek, doğa ve insan arasındaki bağı ortaya koymak ve doğanın insanmerkezci dünya görüşü nedeniyle maruz kaldığı yıkımın önüne geçmek amacındaki ekoeleştirel çalışmalar, zamanla değişen koşullar ve önem kazanan sorunlara bağlı olarak çevresel adalet, ekolojik haklar, küreselleşme, yerli mücadelesi, küresel gida krizi, kent ekolojisi gibi birbirini etkileyen pek çok alanı kapsayarak genişlemiş, tüm kültürel ürünlerin bu meseleler üzerinden incelendiği bir sosyal bilimler disiplini haline gelmiştir. İnsanın ekosisteme zarar veren toplumsal, politik, ekonomik sistemlere karşı çıkmasının ilk aşaması, gezegenin tüm kaynaklarını yağmalayan ve eşitsizliğe dayalı mevcut sistemin sürdürülemez 
olduğunun farkına varmasıdır. Farkındalık ve bilinç değişikliği gerçekleştirilmeden bir sonraki aşama olan eylemlilik gerçekleştirilemez. Ekoeleştiri, tutum ve davranış değişikliğine giden yolda bireylerin zihinsel farkındalık kazanmaları için önemli bir alandır.

\section{Ekomerkezci Bir Film Eleștirisi}

1990'lardan beri önemli bir akademik çalışma alanı olarak kabul edilen ekoeleştiri, metin analizinin ötesine geçerek müzik, fotoğraf, film gibi çok çeşitli kültürel ürünleri ele almaktadır. Karla Armbruster ve Kathleen Wallace, Beyond Nature Writing: Expanding the Boundaries of Ecocriticism (Doğa Yazınının Ötesinde: Ekoeleştirinin Sınırlarını Genişletmek) adlı derlemelerinde ekoeleştirinin en önemli görevinin, daha geniş bir yelpazedeki metinlere atıfta bulunmak için kendi sınırlarını genişletmek olduğunu söylemişlerdir. Geniş kapsamlı araştırma alanı nedeniyle ekoeleştiri metodolojik ve teorik olarak eklektiktir ve akademide yaygın kabul görmüş varsayımları, doktrinleri veya prosedürleri yoktur. Scott Slovic de benzer şekilde, ekoeleştirinin her gün dünya çapında binlerce edebiyat akademisyeninin alandaki çalışmaları tarafından yeniden tanımlandığını, yapılan her ekoeleştirel çalışma ile alanın sınırlarının genişlediğini belirtmiştir. ${ }^{30}$ Nadia Bozak, The Cinematik Footprint (Sinematik Ayak İzi) adlı kitabında "Ekoloji, tanımı gereği sınırlandırılmamıştır, doğanın nerede bittiğini ve kültürün nerede başladığını söylemek imkânsızdır, ya da tam tersini" diyerek ekoloji gibi ekoeleştirinin de kesin sinırlar ile belirlenemeyeceğini vurgulamıştır. ${ }^{31}$

Sinemanın kültürel uzlaşma rolü film ve medya araştırmacıları tarafından uzun zamandır ele alınmakla birlikte doğal dünya ve kültürel alan arasındaki ilişkide oynadığı rol yakın zamana kadar büyük oranda ihmal edilmiştir. 1990'lardan itibaren sinemanın bir yandan üretim, dağıtım, tüketim ve yeniden dolaşım deneyimlerinin doğal kaynaklara etkisi ele alınırken, diğer yandan sinematik metinlerin doğal dünyaya dair görsel-işitsel temsillerinin imgelemimizi etkileyerek dolaylı şekilde dünyaya karşı davranışlarımızı biçimlendirmedeki etkisi incelenmiştir. ${ }^{32}$

Michael Branch, ekoeleştirinin kültürel değişim için bir çağrı olduğunu belirtmiştir. Ekoeleştiri sadece kültürel metinlerde doğayı analiz etme yolu değil, küresel topluluk algısında ve etikte bir genişleme, daha biyo-merkezli bir dünya görüşüne doğru ilerleme çabasıdır. ${ }^{33}$ Eko-film eleştirmenleri için sinema ve eko-sinema çalışmaları, dünyayı algılama biçimimizi dönüştürerek ahlaki evrenin merkezine insan arzularını koyan sınırlı çerçevenin dışında- 
ki olanakları görmemizi sağlar. ${ }^{34}$ Paula Willoquet-Maricondi çeşitli filmlerin ekoeleştirel açıdan incelenmesinin daha iyi bir görsel okur-yazarlığı geliştirmeye iki yoldan yardımcı olduğunu belirtmiştir: İmajların inşasının insandışı dünyaya yönelik algıları ve tavırları biçimlendirmede nasıl çalıştıklarını anlamamıza yardım ederek ve ikinci olarak da doğanın ve çevre sorunlarının görsel temsillerinin tarihsel, kültürel ve ideolojik boyutları konusundaki tartışmaları canlandırarak. ${ }^{35}$ Pietari Kääpä, küresel bir toplumda politik ve kültürel meseleleri tartışmak için en etkili yollardan birinin sinema olduğunu belirtmiştir. Sinemanın ulusötesi ve hatta küresel ölçekli ekolojik sorunları görsel ve işitsel olarak kayıt altına alma ve bunları küresel ölçekte geniş izleyiciler karşısında ifşa etme potansiyeli vardır. ${ }^{36}$

Sinemada ekoeleştirel yaklaşım, doğanın kurmaca, belgesel, deneysel filmlerde ele alınışını inceleyen bir çalışma alandır. Doğanın ve insan-doğa ilişkisinin filmlerde temsil edilme biçimlerini ekolojik bir bakış açısıyla analiz ederek bunların olumlu ve olumsuz etkilerini araştırır. Küresel ekolojik meselelerin tartışmaya açılması, sorunların politik ve kültürel kaynaklarının anlaşılabilmesi için sinema önemli bir aracıdır. Doğaya yönelik algılarımızın kültürün dolayımından geçtiğini, günümüz kültürünü biçimlendirmede küresel çaptaki seyircilere ulaşan sinemanın taşıdığı önemi göz önünde bulundurduğumuzda, sinemada ekoeleştirel çalışmaların önemi daha iyi anlaşılmaktadır.

İnsanın ekosisteme verdiği zararın boyutları hâlâ tam olarak ölçülemezken filmler aracılığıyla da farklı türde kıyamet senaryoları üretilmektedir. Bu filmlerin bazılarında doğa varlıkları insan uygarlığını tehdit etmekte ve uygarlığın karşısında konumlandırılmış olan doğa varlıklarının kontrol altında tutulması gerektiği izleyiciye anlatılmaktadır. Bazı filmlerde ise günümüz insan uygarlığının geldiği noktanın, tüketime ve sömürüye dayalı ekonomik yapının ve savaşa dayalı politikaların doğaya verdiği zararlar ortaya konulmaktadir.

Ekoeleştiri analiz için kuramsal bir çalışma yöntemidir, ancak temelde bir eleştiri yöntemi değildir, kendine ait sağlam ve yerleşmiş yöntemleri yoktur. David Ingram, geleneksel sosyal bilimler yöntemlerini bu disipline uygulanacak şekilde adapte etmiş, sinemada ekoeleştirel yöntemin gelişmesine önemli katkı yapmıştır. Sadece doğayı merkeze alan kurmaca ve belgesel filmler değil, işlediği konu ve türden bağımsız olarak her film ekoeleştirel yaklaşımla analiz edilebilmektedir. Ekosistemin insan olmayan üyelerinin filmlerdeki temsili, bu temsillerin yanlışlığı/yokluğu ekoeleştirinin ilgi alanındadır. Kültür ve doğanın filmlerdeki inşa edilme biçimleri, insan öykülerinin doğa 
içindeki konumlanışı, doğanın insan faydasından bağımsız olarak taşıdığı değerin anlatılması ya da görmezden gelinmesi gibi pek çok başlıkta filmler ele alınabilmektedir.

Marc Ferro Sinema ve Tarih kitabında kurmaca filmlerin de belgeseller kadar tarihi kaydeden araçlar olduğunu, filmlerin içindeki ayrıntıların 'görünür olan' boyunca 'görünmez olanı' keşfetmeye yardım ettiğini vurgulamıştır. Belge filmler ve haber filmleri gibi kurmaca filmlerde de beklenmeyenin, istenmeyenin payı büyük olabilir. Bu filmler amaçlanandan daha fazla gerçeği göstermiş olabilirler. ${ }^{37}$

Varsayımımız şudur: film, gerçeğin görüntüsü olsun ya da olmasın, ister belge ya da kurmaca, isterse gerçek ya da tümden düşsel entrika olsun, Tarih'tir; postulatımız da şu: cereyan etmemiş olan şey (ve neden olmasın, aynı şekilde cereyan etmiş olan şey de), insanın inançları, niyetleri, imgeseli, en az Tarih kadar Tarih'tir. $^{38}$

Aldo Leopold'ün insanın ancak gördüğü, hissettiği şeylere karşı etik davranabileceğini söylemesi gibi, Ferro da "Hiç görülmemiş olan, aynı zamanda ve özellikle, hiç hissedilmemiş olandır" der. ${ }^{39}$ Eko-sinemanın ve ekoloji merkezli bir film eleştirisinin gücü ve önemi burada yatmaktadır: Varlığımızın bağlı olduğu ancak görmeyi ve buna bağlı olarak etik davranmayı unuttuğumuz doğayı bize hatırlatır. İnsan türü olarak ekosistemin merkezinde olmadığımızı, diğer canlı/cansız varlıklarla aynı dünyayı paylaştığımızı, tarihimizin ve kültürümüzün doğadan ayrılamayacağını ortaya koyar. Belgesel ya da kurmaca film olsun, doğanın doğru ya da yanlış temsillerini analiz eden ekoloji merkezli bir film eleştirisi, doğanın filmlerdeki varlığı kadar yokluğunu da kayıt altına alarak kültürümüzü sorgular.

\section{Ekolojik Kıyamet Senaryoları ve Ekolojik Adalet}

Bilimkurgu sineması, günümüzün kaygılarını, korkularını başka bir zaman ve mekâna taşıyarak olası felaketleri ya da çözüm yollarını önermesi bağlamında ekolojik meselelerin algılanmasına büyük katkı sağlayabilme potansiyeline sahiptir. Kiyamet ve kıtlık senaryoları, olası gelecek vizyonları sunarak toplumun beklentilerini ve korkularını tasvir eden, insan türünün felaket karşısında ya da kaynakların sadece bir grup insana yeteceğine inandıkları zaman halkın belli bir kısmını "insan olmayan öteki" olarak görme eğilimini ve kaynakların sınıfsal tahakküm aracı olarak kullanılmasını ele alan, tüm sorunların çözümü olarak sunulan teknolojik gelişmelerin kimlerin yararına olduğunu sorgulayan filmlerdir. 
Darko Suvin'in belirttiği gibi, bilimkurgu türü amprik zamanın ve uzamın, amprik algılamalarımızla bilip öğrendiğimiz gerçeklerin dışında öğeler ve karakterler kullansa da yaşadığımız dünyanın daha doğru, aslına uygun bir temsilini sunma potansiyeline sahiptir. Bilimkurgu metinleri, reel dünyayı aşmak için izleyicisini dış gerçekliğe yabancılaştırarak daha insanca bir dünyaya erişmeyi amaçlar. ${ }^{40}$ Ünsal Oskay'a göre gerçek bilimkurgu anlatıları, mevcut gerçekliğin tanrısal ve değiştirilemez olmadığını, tüm zorluklara rağmen hayatın insan eliyle değiştirilip daha insani değerler üzerinde yeniden kurulabileceğini fark etmemizi sağlar. ${ }^{41}$

Böylece, bilinmeyende ve yeni olanda yeni bir dünya, ideal bir yaşam ortamı, ideal bir kabile, ideal bir devlet, ideal bir toplum yaşamı ararken 'vadimize' ya da 'kendimize' tuttuğumuz 'ayna', artık yalnızca yansıtıcı bir ayna olmaktan çıkmakta; değiştirici (transforme edici) bir ayna olmaya yönelmektedir. ${ }^{42}$

Tanınmış fantezi ve bilimkurgu yazarı Ursula K. Le Guin, bu türlerin özünde okuyucunun mevcut dünyasına alternatifler sunduğunu vurgular. Yazara göre fantezi ve bilimkurgunun önemi kesin ve belirlenmiş bir iyileşme umudu sunmasından ziyade hayal ürünü olan, ama ikna edici bir alternatif gerçeklik önermesindedir. Mevcut koşulların, yaşam biçiminin tek seçenek olmadığını göstererek daha cesur düşünmemize yardım eder. Adaletsiz düzenin devam etmesine, sorgulanmamasına izin veren şey bizim yaşamanın yeni yollarını düşünmek konusundaki tembelliğimiz ve ürkekliğimizdir. ${ }^{43}$

Bilimkurgu, geleneksel Hollywood sineması içinde, ekolojik ve sosyal meselelerden biçimsel olarak ve tarihsel bağlam içinde en çok etkilenen türdür. Bu janr, teknoloji ve insanlığın karşılıklı etkileşim halinde olduğu, birbirlerini ölçüp biçtikleri özel bir tür alanı merkeze alır. Çağın umutlarını, dileklerini, korkularını, içsel gerilimlerini açığa vurur ve sınırlılıklarını ortaya koyar. Bilimkurgu filmleri, Brereton'un vurguladığı gibi, doğaları gereği içinde yaşadığımız ve kesin olarak kabul ettiğimiz dünyayı sorgulama eğilimindedir. ${ }^{4}$ Douglas Kellner, metinlerin ideolojik değerlendirmesi ve medya kültürünün gösterilerinin ötesine geçerek bunların toplumun umutlarını, korkularını nasıl sahnelediğini, ideolojik söylemleri ve politik duruşları nasıl yaydığını incelemek gerektiğini belirtmiştir. Medya kültürü içinde toplumların hayalleri, arzuları sahnelenmekte, bu yolla toplumsal eleştiri ve politik karşıtlığı harekete geçiren ütopik bir içerik sunulmaktadır. Medya gösterileri yoluyla çă̆ın önemli kaygılarını gözlemlemek, neden popüler hale geldiklerini araştırmak mümkündür. ${ }^{45}$ 
Bilimkurgu filmler ekomerkezli bir bakış açısı ile ele alındığında mevcut gerçeklikten yola çıkan, geleceğe yönelik öngörüler ve sorular çıkar karşımıza: Başka bir gezegende, başka bir zamanda, başka bir teknoloji ile yaşayan canlıları düşündüğümüzde onları nasıl tasvir ediyoruz? Gelecekte insan medeniyetini, ekosistemi, doğa ve kültür arasındaki ilişkiyi nerede, hangi biçimde görüyoruz? Geleceğe dair düşleyebildiğimiz en güzel yaşam ve en kötü yaşam nasıldır? Bugünkü kültürümüz, mevcut ekolojik koşullar, teknolojik gelişmeler, sosyal sistemler ışığında baktığımızda gelecekteki "cennet" $i$ ve "cehennem"i nasıl anlatırız? "Cennet" ve "cehennem"e dair beklentilerimizin ve korkularımızın filmlerdeki temsilleri bize günümüze dair neler söyler, algılarımızı ve buna bağlı olarak eylemliliğimizi nasıl değiştirir?

Teknolojinin ve kapitalizmin geldiği aşamada sömürüye dayalı insan medeniyetinin doğayı mutlak biçimde ortadan kaldıracağı, ekolojik yıkımın bedelini alt sınıfların ödeyeceği ve kaynakların eşitsiz paylaşımının yeni bir tür tiranlığın doğuşuna zemin hazırlayacağı öngörüsü Avatar, Açlik Oyunlarn serisi, Elysium, Mad Max, Snowpiercer gibi son dönem popüler bilimkurgu filmlerde ön plandadır. Bu noktada gelecek vizyonunu başka zaman, başka mekân tasavvurları üzerinden ortaya koyan bilimkurgunun tür olarak önemi ortaya çıkmaktadır. Bilimkurgu, aslında bugün ve burasıdır. Mevcut gerçekliğimizi ifade etmek için gelecekte bir evren kurarken günümüz kültürel, toplumsal, politik ve ekonomik koşullarından yola çıkılır. Bu filmler ekolojik mahşer sonrası bir dünyada kıt kaynakların sosyal ve çevresel adalet ekseninde nasıl bir baskı ve denetim mekanizması haline geleceğine dair endişelerin dile getirildiği popüler kültür metinleridir.

Söz konusu filmler gelecekteki ekolojik felâketler üzerine kurulmuş popüler anlatılar olmakla birlikte, yeni dönemde kıyamet senaryosu filmlerinde soruların ve çözüm yollarının teknolojik boyutundan çok -ya da bununla birlikte- sınıfsal gelecek vizyonları öykünün odağında işlenmiştir. Ayrıca ekolojik sorunların çok boyutlu, karmaşık ve birbirini zincirleme reaksiyonlar halinde güçlendiren etkileri olduğu vurgulanmaktadır. Beklenmedik bir anda gerçekleşen dev bütçeli seyirlik felaketlerin (meteor, sel, patlama, deprem, vb.) ve bunların ileri teknolojiler ve kahramanın cesareti sayesinde üstesinden gelinmesi öykülerinin yerini şirketlerin, hükümetlerin açgözlülüğü veya ihmalkârlığı nedeniyle sürecin yıllara yayılan, birbirini tetikleyen ve giderek artan etkisine daha fazla yer veren filmler almaktadır.

Avatar neoliberal sömürgeciliğin Dünya gezegenini yaşanılmaz hale getirdikten sonra gezegen-ötesi boyuta ulaşmasını anlatır. Yönetmen ve senarist 
Cameron Ortadoğu petrolü, Afrika elmas madenleri veya Amazon ormanları mücadelesinden aşina olduğumuz bir sömürgecilik öyküsünü başka bir zamana, başka bir gezegene, başka canlı türlerine taşıyarak anlatır. Pandora gezegenindeki zengin maden yataklarını ele geçirmek isteyen şirket ve ordu ortaklığındaki sömürgeci güçler, doğa ile uyum içinde yaşayan yerli halk Na'vileri kutsal yuvalarını terk etmeleri için ikna etmeye çalışır. Sömürgeciler bilim ve teknolojinin yardımıyla yerli halka benzeyen ancak insanlar tarafından kontrol edilen yarı Na'vi yarı insan olan avatarlar üretip içeriden bilgi almaya çalışırlar. Görevi yerlilerin arasına sızıp içeriden bilgi getirmek olan eski asker Jake, avatar bedeninde Na'vi yaşamını deneyimledikçe Pandora doğasına ve doğanın bir parçası olarak yaşayan Na'vilerin kültürüne hayranlık duyar. Avatar projesinin başındaki bilim insanı Grace, Jake ve birkaç arkadaşı yetkilileri gezegendeki doğa-kültür zenginliğinin madenlerden daha değerli olduğunu anlatmaya çalışırlar. Sömürgeci güçlerin saldırıya geçmesiyle Jake liderliğindeki Na'viler gezegenlerini savunmak için mücadele eder ve sonunda işgalci güçleri gezegenlerinden kovarlar.

Snowpiercer, küresel ısınmaya çare olması için bulunan teknolojik çözümün beklenmeyen tepkimelere yol açıp tüm dünyayı buzullarla kaplı hale getirdiği bir gelecekte geçer. Dünyayı buz kaplarken neredeyse tüm canlılar yok olur ve sağ kalan insanlar donmamak için sürekli hareket eden bir trende yaşamlarını sürdürürler. Trenin ön kompartımanlarında zenginler için canlı hayvan ve bitki türleriyle "doğal" hale getirilmiş bolluk içinde bir yaşam sağlanırken fakirler en arka kompartımanda açlık ve sefalet içinde hayatta kalmaya çalışırlar. Trenin kontrolünü ele geçirmeye çalışan alt sınıftan isyancılar lokomotife ulaştıklarında trenin mucidi ve sürücüsü olan Wilford'ın kendilerini beklediğini görürler. Yaşlandığı için yeni bir sürücüye ihtiyaç duyan Wilford isyanı kendisi teşvik etmiştir. Bu sırada ölenler trendeki "aşırı nüfus" tur ve ölümleri ile nüfus yeniden dengelenmiştir. Alt sınıftan küçük çocukları trenin bozulan parçaları yerine işlev görmeleri için kullanarak lokomotifin/sistemin bir parçası haline getiren Wilford'a göre tren tüm bir ekosistemdir. Sınıf sistemine dayalı ve zayıfların yok olduğu bir hiyerarşik ekosistem tasvir eden Wilford, isyancıların liderinden yeni sürücü olmasını ister. Sürücü kim olursa olsun trende kaldıkları sürece adaletsiz sistemin devam edeceğini anlayan isyancılar adaletsiz bir yaşam yerine buzlarla kaplı ölü dünyada hayatta kalmayı denemeye karar verir ve treni raydan çıkarırlar. Filmin karanlık tonuna rağmen final sahnesinde geleceğe yönelik umut yeşertilir. Trenden inenler buzullar arasında dolaşan bir kutup ayısı görürler. Dünya kendini onarmaya, yeniden canlanmaya başlamıştır. 
Elysium filminde dünyada artan kirlilik, canlıları zehirleyen gazlar, kıtlık ve aşırı nüfus yüzünden seçkinler Elysium adlı uyduda yeni bir yaşam kurmuşlardır. Üst sınıflar bu yeni “cennet” te yeşil bahçeler içinde hastalık ve yaşlılığın olmadığı bir hayat sürerken alt sınıflar dünyada hastalık, çeteler, yoksulluk ile mücadele etmeye çalışırlar. Elysium' da her evde bulunan sağlık biriminde tüm hastalıklar tek bir cihazla tedavi edilirken alt sınıfların uyduya girişi yasaktır. Çeteler, Üçüncü dünya ülkelerinden Avrupa'ya kaçmaya çalışan mültecileri taşıyan günümüz insan kaçakçıları gibi, yüksek fiyatlar karşılığında hastaları yasadışı olarak Elysium'a taşırlar. Dünyayı zehirleyerek yaşanılmaz hale getiren dev şirketler ve üst sınıflar kendilerine ileri teknoloji sayesinde yeni bir yaşam kurmuştur ancak açlık ve hastalık alt sınıflar için kaçınılmazdır. Dünyada üretime devam eden kirli endüstrilerde, can güvenliği olmayan tehlikeli işlerde alt sınıflar çalışmaktadır. Teknolojik ilerleme, gelişme gerçekten gelecekte gezegenimizi kurtaracak mi, yoksa sınıflı toplum ve sermayenin iktidarı devam ettiği sürece ekolojik yıkımın bedelini sadece alt sınıflar mı ödeyecek? Filmin sonunda kahramanın kendi hayatı pahasına, alt sınıfları uydudan uzak tutan, bedenlerine işlenmiş olan sınıfsal kodları okuyan yazılımı ortadan kaldırması ile daha adil bir yaşam için umut doğar.

Dört filmden oluşan Hunger Games serisinde şiddete ve gösteriye dayalı bir iktidarın, yurttaşları sefalet ve aşırı tüketim karşıtlığında yönettiği bir ülke tasvir edilmiştir. Başkent Capitol ve 12 mintıkadan oluşan Panem adlı ülkede her mintıka Capitol'ın lüks ve zenginlik içinde yaşaması için belirlenmiş bir alanda üretim yapmakta, mıntıka halkları ise açlık ve sefalet içinde yaşamaktadır. Panem'de 74 yıl önce Capitol tarafından 13. Mıntıka'nın tamamen yok edilmesi ile bastırılmış isyanın bir daha yaşanmaması için mıntıkalar sürekli gözetim altında tutulmakta, "Açlık Oyunları" adı verilen vahşete dayalı bir gösteri ile eylemsiz hale getirilmektedir. Capitol halkı aşırı tüketim ve gösterinin heyecanı ile büyülenirken Mıntıka halkları açlık, sefalet ve ölüm korkusu ile kontrol edilmektedir. Açlık Oyunları, her mintıkadan kura yoluyla "hasat edilen" ve "haraç" adı verilen 12-18 yaş aralığındaki birer kız ve erkek çocuğunun tek bir galip kalana kadar birbirlerini öldürmeleri ve sağ kalanın ömrünün sonuna kadar zenginlik içinde yaşamasına dayalıdır. 74. Açlık Oyunları'nda arenaya gönderilmek üzere kız kardeşinin seçilmesi üzerine Katniss gönüllü olur ve doğayı tanıması, avcılık deneyimi sayesinde hayatta kalır. Bu arada 12. Mıntıka'dan gelen diğer haraç Peeta ile birlikte hayatta kalmak için gösterinin kurallarına göre hareket eder ve âşık genç kız rolünü oynayarak Capitol vatandaşlarının desteğini kazanır. Antik dönem gladyatör oyunlarında olduğu gibi, Açlık Oyunları'nda da fiziksel güç ve dayanıklılık 
yanında seyircilere iyi bir gösteri sunarak onların sempatisini kazanmak, hayatta kalmanın anahtarıdır. Hunger Games, Katniss' in mevcut sistemin kurallarına uygun hareket ederek herkes için adil ve özgür bir yaşam elde edilemeyeceğini, sistemin ortadan kaldırılması gerektiğinin farkına varmasını ortaya koyar. Katniss'in bir sembol haline geldiği kitle hareketi büyür ve gücü ele geçirmek için vatandaşlarını ölüme gönderen iki liderin de öldürülmesi ile yeni bir toplumsal sistemin ilk adımları atılır.

Hunger Games serisinde, Avatar'da olduğu gibi, ekoeleştirinin temel ilgi alanı olan ve ekosistemin tahrip edilip yağmalanmasında en büyük role sahip olan doğa / kültür düalizmine bağlı bir kültürel inşa olan medeniyet/ barbarlık kavramları ters yüz edilmiştir. Tehditkâr olan ve kontrol altında tutulması gereken "doğa" değil, ileri teknolojiyi insanları öldürmek ve baskı altında tutmak için kullanan insan kültürüdür. Nazilerin İkinci Dünya Savaşı'nda insanları kitlesel olarak "imha" etmek için dönemin tekniklerinden faydalanmasından beri bilimsel ve teknik gelişmişliğin toplumları barbarlıktan kurtarmadığı bilinmektedir. Avatar' da başka gezegenlere gidecek kadar ileri teknolojiye sahip 'medeniyetin' bunu yerli halkları ve ekosistemi sömürmek, yok etmek için kullanması gibi Hunger Games'te ileri teknoloji, en vahşi katliamları gerçekleştirmek için kullanılmaktadır. Sosyal ve çevresel adaletin sağlanmadığıı, toplumun sömürenler ve sömürülenler olarak sınıflara bölündüğü bir sistemde ileri teknoloji, ekolojik yıkım ve katliamın devasa boyutlara ulaşmasinin aracı haline gelmektedir.

Hunger Games'te Capitol (üst sınıflar/ Birinci Dünya) ve Mintıkalar (alt sınıflar/ Üçüncü Dünya) üzerinden günümüz dünyasının sınıfsal, politik, ekonomik ve çevresel adalet meseleleri ortaya konulmuştur. Sorun kaynakların kıtlığı değil, adaletsiz paylaşımı sorunudur. Uzun çalışma saatleri ve kölelik koşulları emek piyasasının gereği değil, emek piyasasını kontrol edenlerin kendi ayrıcalıklarını korumasının sonucudur. Çevre ile bağı koparılan, zengin kuzey ülkelerinin ihtiyaçlarını karşılamak için ekolojik dengeyi bozacak şekilde tek tip üretime mahkûm edilen az gelişmiş ülkeler, ekonomik olarak bağımlı oldukları ülkelerin tahakkümü altındadır. Capitol'de yaraları bir gecede iyileştiren kremler, canlıların genlerine müdahale eden teknoloji mevcuttur ancak mıntıkalarda insanlar basit hastalıklardan ölmekte, temel sağlık ve besin ihtiyaçlarına bile ulaşamamaktadır. Elysium ve Snowpiercer'da doğal kaynakların tüketildiği veya atıklarla zehirlendiği dünyada teknoloji yardımı ile inşa edilen sağlıklı yaşam alanlarına yalnızca üst sınıfların erişimi vardır. Sadece bu filmlerde anlatılan karanlık gelecekte değil, günümüz dünyasında 
da temel sorun ilacın, gıdanın, temel insani ihtiyaçların eksikliği değil, bunlara erişimi kimin, nasıl düzenlediğidir. Ekolojik ve insani krizlerin kaynağı teknoloji ve bilimin geri kalması ya da aşırı gelişmesi değil, seçkin azınlık tarafından kitleleri kontrol etmek, ekonomik ve politik gücü elde tutmak için kullanılmasıdır.

Sayısız gıda politikası yazarının işaret ettiği gibi, dünyadaki herkesi besleyebilecek kadar gıda üretebiliyoruz. Açlık yetersiz üretimin sonucu değil, yapısal olarak yaratılan bir sorundur. Sosyolog Harriet Friedman'ın "Gida politikaları sınıf politikalarının bir vehçesidir" sözünü hatırlatan Burke, küresel olarak kökleşmiş ve politik olarak onaylanmış ırkçılığın gıdaya ulaşmada eşitsizlik yarattığını, bunun da bir çevresel adalet sorunu olduğunu belirtmiştir. ${ }^{46}$ Gelişen teknolojinin ve bilimin kapitalizmin hizmetinde olmasının ekosistemde yol açtığı hasarın (atıklar, hammadde için doğanın sömürülmesi, radyoaktif sızıntılar, vb) yine bilim ve teknoloji sayesinde çözülebileceğini öne süren, GDO'lu gidalar gibi doğal dengeyi tahrip eden uygulamalarla küresel açlık sorununa çözüm bulunabileceğini savunanlara karşı, çeşitli düşünürler "kıtlık" kavramının tanımını tartışmaya açmakta ve teknolojinin politikadan bağımsız olmadığının altını çizerek yanıt vermektedirler.

Raj Patel'in Stuffed and Starved: The Hidden Battle for the World Food System (Tıkabasa ve Açlıktan Kırılan: Dünya Gıda Sistemi için Gizli Savaş) kitabında açıkladığı gibi Dünya Ticaret Örgütü ve Dünya Bankası'nın kredi ve patent anlaşmaları, Avrupa Birliği ve Amerika'ya Küresel Güney üzerinde görülmemiş bir güç vermiştir. Zengin Kuzey kendi stratejik gida rezervlerini korumaya alırken Küresel Güney ülkelerini kendi tarımsal üretimleri üzerindeki haklarından, biyo-çeşitlilikten feragat etmeye ve Kuzey'i besleyecek tek tip üretim yapmaya zorlamakta, monokültüre mahkûm etmektedir. Giderek daha fazla sayıda zengin ülke, Hunger Games'te Capitol'un yaptığı gibi, beslenme eksikliği ve açlık çeken nüfusa sahip ülkelerden gıda ithal etmektedir. Bu ülkeler artık bir besin demokrasisine sahip olamamakta ve yaratılmış bir sisteme bağımlı hale gelmektedir. Çevresel Adalet aktivisti Robert Bullard, tüm çevresel adalet meselelerinin temelinin imparatorluk etiğine, toprağın ve insanlarının fethine dayanan değerlere uzandığını yazmıştır. Mevcut ekonomik sistemin insanları ve toprağı birbirine bağladığı nokta, ikisini de eşit şekilde tüketilebilecek ticari değerler olarak görmesidir. ${ }^{47}$

Hunger Games küresel çaptaki ekolojik ve sosyal adaletsizliğin, gösteriye dayalı bir iktidarın vardığı son nokta olarak “cehennem"dir. Dört filmden oluşan seride meta-mekân kullanımıyla çifte cehennem tasavvur edilmiş- 
tir. Panem ülkesi alt sınıflar ve yoksul ülke vatandaşları için gelecekteki bir "cehennem" dir; aynı zamanda oyun kurucular haraçlar için insan kontrolünde olan ama "doğal" görünen bir cehennem, "arena" inşa eder. Elysium' da Dünya gezegenini cehenneme çevirenler uyduda bir "cennet" kurmuştur; ancak alt sınıflar zehirli gazlar, endüstriyel atıklar içindeki "cehennem" de yaşamaya mecbur bırakılmıştır. Snowpiercer'da benzer şekilde dünyayı önce küresel ısınma ile çölleştiren, daha sonra buna çözüm bulmak için buzlarla kaplanmasına neden olan, aşırı endüstrileşme, bilimin ve teknolojinin yanlış kullanımıdır. Trenin ön kompartımanlarında üst sınıflara bir "cennet" inşa edilirken alt sınıflar açlık ve sefalet içinde "cehennem"i yaşarlar. Avatar'da Pandora gezegeni bir kayıp cennet tasavvuru ise bu cenneti yok eden de insan türünün açgözlülüğü ve doğadan kopuk yaşam biçimidir. Ordu-şirket ortaklıkları Dünya gezegenini yaşanılmaz hale getirdikten sonra teknolojinin de yardımıyla başka gezegenleri yağmalamaya başlamış, insan türü $\mathrm{Na}^{\prime}$ vilerin mavi cennetini cehenneme çevirmiştir.

Avatar gibi küresel ölçekte milyonlarca seyirciye ulaşan bir filmin bölgesel okumalarının en çarpıcı örneklerinden biri Filistin direnişi tarafından ortaya konulmuştur. Filistinli köylüler, şiddete dayalı olmayan direnişin aktivistleri ve Duvara Karşı Anarşistler adlı İsrailli Yahudi grup üyeleri kendilerini Na'vi mavisine boyayarak Batı Şeria boyunca uzanan ve Yahudi yerleşim yerlerini Filistin köylerinden ayıran Ayrılık Duvarı'nı (Separation Wall) protesto etmişlerdir. ${ }^{48}$ Yukarıdan, baskın kültür tarafından üretilmiş filmin alttaki ezilenleri harekete geçirmek konusunda tarihte bir başka örnek olmadığını söyleyen Loshitzky'ye göre, kurumsal kapitalizm mantığı içinde üretilmiş bir Hollywood filmi tüm bunlara rağmen yıkıcı olarak okunmuş, baskı altındaki halkı mücadele etmek konusunda harekete geçirmiştir. Yazar, Avatar'ın sömürge karşıtı taban hareketlerini mobilize etme gücünün geleneksel politik film algısına dair temel sorular sordurduğunun altını çizmiştir. ${ }^{49}$

Yavaş Şiddet kitabının yazarı Rob Nixon'ın da vurguladığı gibi, dünyada gösteri üzerinden sürüp giden bir savaş vardır ve gişe rekortmeni filmler, belgeseller küresel çevresel adalet mücadelesinde önemli bir rol oynamaktadır. Joni Adamson, dünya çapındaki yerli gruplarının (Amazon yerlileri, Filistinli protestocular) kendi bölgesel hareketlerini Avatar'la ilişkilendirmelerinin nedeninin gişe rekortmeni bir filmin Hindistan ya da Amazon'da geçmesi değil, Avatar'ın bu meselelerin kamusal hale gelmesine yardımcı olması olduğunu belirtmektedir. ${ }^{50}$ Filmin kahramanı Jake' in elindeki taşla ileri teknoloji ürünü dev bir yıkıcı araca karşı koymaya çalışması, ulusötesi şirketlere, güçlü ülke- 
lere karşı topraklarını, doğalarını ve yaşam haklarını savunmaya çalışan tüm halklar için ikonik bir sahnedir. Günümüzde ekonomik ve askeri olarak güçlü sömürgecilere karşı özgürlük ve adalet için koşulların eşit olmadığı bir savaşta direnmeye devam eden insanlar için, filmin sonunda işgalcilerin geldikleri gezegene geri gönderilmesi, zafere duyulan umudu beslemekte ve ilham verici olmaktadır.

\section{Sonuç}

Son yıllarda giderek artan sayıda bilimkurgu filmi, radikal ekolojik hareketlerin de ısrarla ortaya koydukları gibi, mevcut sistem içinde kalındığı sürece sadece teknolojideki gelişmelerle ekolojik yıkımı, sosyal ve çevresel adaletsizliği ortadan kaldırmanın imkansız olduğunu ortaya koyar. Ekolojik ç̋̈küşün kaynağı gibi çözümü de politiktir. Popüler sinemanın çelişkili biçimde de olsa mevcut sistemin devamı halinde insanlığın sağlıklı bir çevrede yaşamasının mümkün olmadığı, ekolojik krizin önlenmesinin en önemli koşulunun sistemi değiştirmek olduğunu vurgulaması azımsanamayacak kadar önemlidir. İçinde bulunduğumuz toplumsal ve ekolojik yıkımın kökleri kültürel, ekonomik, politik sistemimizde bulunmaktadır. Ekosistemin işleyişini ve insanın ekosistemin bir parçası olduğunu anlamadan, bu işleyişe saygı göstermeden, tüketime dayalı, sınıflı, cinsiyetçi ve sömürgeci bir kapitalist sistemin ortadan kaldırılması mümkün değildir. Ele alınan filmler günümüzün gerçeklerini ve acil meselelerini başka bir zamana/ başka bir uzama taşıyarak bugünün sorularına cevap vermeye çalışmakta, bir gelecek vizyonu sunmaktadir.

Bir ekolojik kıyametin ardından hangi toplumsal sınıflara ne olacaktır? Çalışmada ele alınan filmlerde besin kitlı̆̆ı, zehirlenmiş atmosfer, kimyasal atıklarla kirlenmiş toprak tüm sınıfları aynı şiddette etkilememektedir. Teknolojide yaşanan gelişmelerin kime faydası olacaktır? Son yıllarda ekolojik yıkımı ele alan popüler filmlerde öncelikle sinıflı toplum yapısının, mevcut adaletsiz sistemin ortadan kaldırılması gerektiğine yapılan vurgu dikkat çekmektedir. Sosyal ve çevresel adalet, ekoeleştirinin en canlı kollarından biridir ve ekolojik yıkıma da neden olan sistemin temel sorunlarını net biçimde ortaya koymaktadır. Sınıflı toplum, adaletsizlik, sömürü devam ettiği sürece yeni bir gezegende bir cennet yaratılsa bile, bu cennetin kimler için olacağı sorusu cevap beklemektedir. Karanlık ve umutsuz tonda başlayan bu filmler, doğrudan mevcut sistemi yıkmaya yönelik eylemlerin gerçekleştirilmesi ile kurtuluşun mümkün olabileceğini ortaya koyarak geleceğe yönelik umudu 
besleyen argümanlarla sona ermektedir. Treni raydan çıkarmadan, kubbeyi yıkmadan, işgalciyi kovmadan, insanları eşit gören sistem başlatılmadan herkes için ekosistemle uyumlu, çevresel adaletin sağlandığı bir sistem kurulamaz.

Bu filmlerde ekolojik sorunların karmaşıklığının daha fazla yer bulması, teknolojik çözümlerin sosyal sorunlar çözülmeden herkese faydalı olmayacağı (Elysium, Hunger Games, Snowpiercer), adil bir toplum inşa edilmediği sürece bilim ve teknolojideki gelişmelerin azınlığın tahakkümünün ve sömürgeciliğin aracı olacağı (Avatar, Hunger Games, Elysium) siyaset-sermaye-ordu suç ortaklığı devam ettikçe ekolojik yıkımın başka bir gezegende bile kaçınılmaz olduğu (Avatar), işgalci uzaylı stereotipinin insan açgözlülüğü karşısında mülteci durumuna düştüğü (Avatar) anlatıları yaygınlaşmıştır. Teknoloji ve bilime duyulan güvenin yerini bunların yanlış ve kötücül kullanımından doğan sonuçların sorgulanması almış, barbarlık ve modernlik tanımları tartışmaya açık hale gelmiştir. Avatar' da doğa ile uyum içinde yaşayan "vahşi”leri katleden, gezegeni yağmalayan, gelişmiş teknolojiye sahip "modern" toplumdur. Hunger Games' te teknolojinin en gelişkin halinin barbarlık için kullanıldığı, yüzyıllar öncesindeki gibi ilkel gladyatör oyunlarının ve kamuya açık infazların gözetim/denetim teknolojileri sayesinde daha vahşi biçimde sürdürüldüğü bir ülke tasvir edilir.

Çalışmada ele alınan filmlerde çelişkiler bulunmakta, bu çelişkiler Hollywood'un ticari yapısından kaynaklanmaktadır. Hollywood sineması kasıtlı olarak çelişkili mesajlar içeren anlatılar kurmakta, mümkün olduğunca çok sayıda seyircinin beklentilerini tatmin etmeyi amaçlamaktadır. Sömürgecilik eleştirisi yaparken öykünün beyaz adam gözünden anlatılması (Avatar), yerli geleneklerini seyirlik olarak kullanan turistik bakışa yer verilmesi (Avatar), öykünün dramatik gelişimi için aşk üçgeninin kullanılması (Avatar, Hunger Games), başkarakterlerin beyaz olması (Avatar, Snowpiercer, Elysium, Hunger Games) filmlerin ekolojik meselelere dair mesajlarının gücünü zayıflatan çelişkilerdir. Ancak Hollywood gelenekleri içinde ekolojik meselelerin dile getirilmesi ve geniş kitlelere ulaştırılması önemlidir. Küresel çapta milyonlarca izleyiciye ulaşan filmler yoluyla öncelikle ekolojik sorunların varlığına ve mevcut kültürel, toplumsal, politik sistemin aksaklıklarına dikkat çekilmesi, bu sorunların çözüm yollarını tartışmak için ilk adımdır.

Örnek film analizlerinin de gösterdiği gibi bilimkurgu sineması sadece mevcut ekolojik meseleleri, geleceğe yönelik korku ve beklentileri yansıtmakla kalmamakta, belirli sorunları görünür hale getirilmesine, gelecek vizyonla- 
r1 ve çözüm önerileri sunarak dünyaya, topluma ve mevcut yaşam biçimine farklı açılardan bakılmasına katkı sağlamaktadır. Ekosistemin kırılganlığı arttıkça popüler sinemanın ekolojik meselelere dair kaygıları temsil etme biçimi değişmekte, sorunların ve çözüm yollarının karmaşıklığı vurgulanmaktadır. Milyonlarca insana ulaşan popüler bilimkurgular, çağdaş kültürel metinler olarak seyircilere yeni yaşam biçimleri, tüm canlılar için daha adil ve daha özgür bir dünya inşa edilmesi olasılığını hatırlatma gücüne sahiptir. Bu güç üzerinde daha çok çalışma yapılması, sinemanın insan ile insan dışı doğa ilişkisini onarmak, ekosisteme yönelik yeni bir duyarlılık geliştirmek, doğanın tüm varlıklarının hakkının gözetildiği yeni bir etik kurmak gibi acil ihtiyaçlara cevap vermek konusunda topluma nasıl yardımcı olacağının anlaşılması bakımından hayati önemdedir. Bu çalışmanın da sinema çalışmaları içinde ekolojik meselelerin çözümüne yönelik çabalara küçük bir katkı yapması hedeflenmiştir. 


\section{Notlar}

1 John Bellamy Foster, “The Long Ecological Revolution”, Monthly Review, 1.11.2017, https: / / monthlyreview.org/2017/11/01/the-long-ecological-revolution/

2 John Bellamy Foster, "Ekoloji ve Kapitalizmden Sosyalizme Geçiş", http://sendika62. org/2010/02/ekoloji-ve-kapitalizmden-sosyalizme-gecis-john-bellamy-foster-40436/ ), 03.02.2010.

3 Kovel, Doğanın, 31.

4 Food and Agriculture Organization of the United Nations, "Global Report on Food Crises 2017", http:/ / www.fao.org/3/a-br323e.pdf, Erişim: 19.02.2018, 15.

5 “The United Nations World Water Development Report 2015", http: / / unesdoc.unesco.org/ images / 0023/002318/231823E.pdf, Erişim: 19.02.2018.

6 Konu hakkında daha fazla bilgi için: http://www.suhakki.org/2014/08/hindistan-25milyon-dolarlik-coca-cola-tesisine-dur-dedi/\#.WjoTSN91_IU, http:// chevrontoxico.com/ about/rainforest-chernobyl/ ,http:// amazonwatch.org/work/belo-monte-dam

7 Joel Kovel, Doğanın Düşmanı, çev. Gürol Koca (İstanbul: Metis, 2005), 42-43.

8 Murray Bookchin, “Yoketme gücü yaratma gücü," çev. Ümit Altuğ, Birikim 57-58 (1994): 48.

9 Daniel Tanuro, Yeşil Kapitalizm İmkansızdır, çev. Volkan Yalçıntoklu (İstanbul: Habitus, 2011), 56.

10 Foster, "Ekoloji"

11 “Ekoloji-Bilim İliş̧kisi Üzerine Tartışmalar”, Birikim 57-58 (1994): 35.

12 Ursula K. Heise, "The Virtual Crowds: Overpopulation, Space and Speciesism", Interdisciplinary Studies in Literature and Environment 8.1, (2001): 3. Erişim: 22.02.2016 http:/ / www.jstor. org/stable / 44087426

13 David Harvey, Sermayenin Mekanları, çev. Başak Kıcır, Deniz Koç, Kıvanç Tanrıyar, Seda Yüksel (İstanbul: Sel, 2012), 65, 85.

14 Harvey, Sermayenin, 88.

15 Harvey, Sermayenin, 90.

16 Rob Nixon, Slow Violence and the Environmentalism of the Poor (Cambridge: Harvard University Press, 2011), 2-3.

17 Nixon, Slow, 5.

18 Greg Garrard, Ekoeleştiri, çev. Ertuğrul Genç (İstanbul: Kolektif, 2016), 186-187.

19 Nixon, Slow, 15.

20 Foster, "The Long Ecological"

21 Serpil Oppermann, "Doğa Yazınında Beden Politikası" http://www.littera.hacettepe.edu. tr/TURKCE/18_cilt/6.pdf , Erişim: 04.11.2014, 5. 
22 Ümit Şahin, "Yeşil hareket bir öncüsünü daha kaybetti: Barry Commoner'ın ardından..." https: / yesilgazete.org/blog/2012 / 10 / 02 / yesil-hareket-bir-oncusunu-daha-kaybettibarry-commonerin-ardindan/, 2.10.2012.

23 Oppermann, “Doğa," 5.

24 Cheryll Glotfelty, "Introduction: Literary Studies in an Age of Environmental Crisis", The Ecocriticism Reader: Landmarks in Literary Ecology içinde, der. Cheryll Glotfelty, Harold Fromm (Athens, Georgia: TheUniversity of Georgia Press, 1996), xx.

25 Paula Willoquet-Maricondi, "Introduction: From Literary to Cinematic Ecocriticism", Framing the World: Explorations in Ecocriticism and Film içinde, der. Paula Willoquet Maricondi (USA:University of Virginia Press, 2010), 3.

26 Glotfelty, "Introduction," xviii.

27 Garrard, Ekoeleştiri, 6.

28 Kovel, Doğanın, 121-122.

29 Garrard, Ekoeleştiri, 24.

30 Willoquet-Maricondi, "Introduction," 1.

31 Stephen Rust, Salma Monani, "Introduction: Cuts to dissolves-defining and situating ecocinema studies", Ecocinema Theory and Practice içinde, der. Stephen Rust, Salma Monani, Sean Cubitt (New York and London: Rotledge, 2013), 1.

32 Rust, Monani, “Introduction," 2.

33 Elizabeth Henry, “The Screaming Silence Constructions of Nature in Werner Herzog's Grizzly Man", Framing the World: Explorations in Ecocriticism and Film içinde, der. Paula WilloquetMaricondi (USA: University of Virginia Press, 2010), 183.

34 Rust, Monani, "Introduction," 11.

35 Paula Willoquet-Maricondi, "Preface", Framing the World: Explorations in Ecocriticism and Film içinde, der. Paula Willoquet Maricondi (USA:University of Virginia Press, 2010), xii-xiii.

36 David Ingram, "The Aesthetics and Ethics of Eco-film Criticism", Ecocinema Theory and Practice içinde, der. Stephen Rust, Salma Monani, Sean Cubitt (New York and London: Rotledge, 2013), 59.

37 Ferro, Marc Ferro, Sinema ve Tarih, çev. Turhan Ilgaz, Hülya Uğur Tanrı̈ver (İstanbul: Kesit, 1997), 32-34.

38 Ferro, Sinema, 32.

39 Ferro, Sinema, 113.

40 Ünsal Oskay, Çağdaş Fantazya (İstanbul: Der Yayınları), 13-14.

41 Oskay, Çağdaş, 40-41.

42 Oskay, Çağdaş, 19. 
43 Maria Popova “Ursula K. Le Guin'den, hayali hikaye anlatıcilığının mümkün olana dair alg1mızı nasıl genişlettiği üzerine", çev. Serap Güneş, 10.05.2016 https:/ / dunyadanceviri.wordpress.com/2016/05/10/ ursulu-k-le-guinden-hayali-hikaye-anlaticiliginin-mumkun-olanadair-algimizi-nasil-genislettigi-uzerine-maria-popova/

44 Pat Brereton, Hollywood Utopia (UK: Intellect Books, 2005), 139-141.

45 Douglas Kellner, Medya Gösterisi, çev. Zeynep Paşalı (İstanbul: Açılım, 2010), s.69-70.

46 Brianna Burke, "'Reaping' Environmental Justice through Compassion in The Hunger Games", Interdisciplinary Studies in Literature and Environment 22 (3) (2015): 547, erişim tarihi: 12.04.2016, doi: 10.1093 /isle/isu099.

47 Burke, “Reaping," 551-552.

48 Yosefa Loshitzky, “Popular Cinema as Popular Resistance”, Third Text, 26 (2) (2012): 151-152, erişim tarihi: 15.07.2016, doi: 10.1080/09528822.2012.663971.

49 Loshitzky, "Popular", 153.

50 Joni Adamson, “Indigenous Literatures, Multinaturalism, and Avatar: The Emergence of Indigenous Cosmopolitics", American Literary History 24 (1) (2012): 156, erişim tarihi: 18.07.2016, doi: $10.1093 /$ alh / ajr053 
$60<$ ilef dergisi 